\title{
Distribution of Neuropeptide $Y$ and Gonadotropin-Releasing Hormone Immunoreactivities in the Brain and Hypophysis of the Ayu, Plecoglossus altivelis (Teleostei)*
}

\author{
Akira ChIBA ${ }^{1}$, Young Chang SoHN ${ }^{2}$ and Yoshiharu HonMA ${ }^{2}$ \\ Department of Biology ${ }^{1}$, Nippon Dental University School of Dentistry at Niigata, Niigata; and Faculty of Science ${ }^{2}$, Niigata \\ University, Niigata, Japan
}

Received November 21, 1995

\begin{abstract}
Summary. This paper reports on the distribution, relationship and seasonal variations of neuropeptide Y (NPY)like and gonadotropin-releasing hormone (GnRH)-like immunoreactants in the brain and hypophysis of the bony fish, the ayu Plecoglossus altivelis. NPY-like immunoreactivity was widely distributed in the brain: labeled cells were found in the nervus terminalis, the nucleus entopeduncularis, the habenula, the nucleus preopticus periventricularis, the nucleus tuberis lateralis, the mediodorsal hypothalamus, the dorsal tegmentum, and other sites. NPY fibers were considerably dense in the telencephalon and hypothalamus, and innervated the hypophysis. GnRH-positive cells occurred in the nervus terminalis and were sparsely distributed in the preoptic and tuberal areas of the hypothalamus. GnRH fibers were found in various regions of the brain. They were relatively dense in the hypothalamus, showing a local concentration in the middle region of the neurohypophysis. The GnRH-positive cells and fibers in the hypothalamo-hypophyseal complex increased in density around the spawning season. In tandem with gonadal maturation, NPY labeling in the cells of the nucleus tuberis lateralis became intense concomitantly with an increase in the labeled varicosities in the middle region of the neurohypophysis. Double immunostaining showed that NPY fibers were closely apposed to GnRH cells in the preoptic area. These results suggest a correlative involvement of NPY and GnRH in the control of the hypophyseal gonadotropic function of the ayu.
\end{abstract}

In teleosts, gonadotropin secretion is mediated by various factors in the brain. Among them, at least two neurohormones have been essentially implicated in the regulation of gonadotropin secretion: the gonado- tropin-releasing hormone $(\mathrm{GnRH})$, and dopamine, a gonadotropin release-inhibiting factor (PETER, 1983; $\mathrm{KAH}, 1986)$. Recently, it has been reported that neuropeptide Y (NPY) stimulates gonadotropin release in the rainbow trout (BRETON et al., 1989, 1991; DANGER et al., 1991), the common carp (BRETON et al., 1991) and the goldfish (KAH et al., 1989; PENG et al., 1990, $1993 \mathrm{a}, \mathrm{b})$ and also growth hormone release in the goldfish (PENG et al., 1990, 1993a, b). Innervation of the teleostean hypophysis by NPY-immunoreactive fibers has been demonstrated by immunohistochemistry in different species: the sea bass (MoONs et al., 1989), the goldfish (PONTET et al., 1989), the trout (DANGER et al., 1991), and the platyfish (MAGLIURO-CEPRIANO and SCHREIBMAN, 1993). Furthermore, NPY gene expression and its regulation by ovarian steroids have been studied in the goldfish (PENG et al., 1994). However, immunohistochemical evidence showing the involvement of NPY in the gonadotropin release is still scanty. Thus, basic data such as the localization, anatomical relationship and seasonal variations of NPY- and GnRH. immunoreactive structures should be further accumulated in relation to the reproductive activities of different species. In the ayu, however, almost nothing is known on this subject.

On the other hand, a growing body of data on $\mathrm{GnRH}$ has been opportunely reviewed (SHERWOOD, 1987; CHIEFFI et al., 1991; KING and MiLler, 1991), and mapping studies of $\mathrm{GnRH}$ immunoreactivity in the teleostean brain and hypophysis have been conducted in several species (MÜNZ et al., 1981; NOZAKI et al., 1985; KAH et al., 1986; 1991; SUBHEDAR and RAMA KRISHNA, 1988;

*This work was partly supported by a grant (No. 06640859 to YH) from the Japanese Ministry of Education, Science and Culture. 
OKA and ICHIKAWA, 1990; AmANo et al., 1991). From the studies so far conducted, three different areas have been recognized as the loci for the source of $\mathrm{GnRH}$ : 1) the nervus terminalis or the nucleus olfactoretinalis; 2) the hypothalamus; and 3) the dorsal area of the midbrain tegmentum. Moreover, in the brains of goldfish (YU et al., 1988) and salmonids (OKUZAWA et al., 1990; AMANO et al., 1991), the differential distribution of different molecular forms of GnRHs, i.e., salmon $\mathrm{GnRH}$ (sGnRH) and chicken GnRH II (cGnRH II), has been reported. These findings suggest different physiological functions for the discrete GnRHs.

We conducted an immunohistochemical examination in the present study to elucidate the topographic distribution, anatomical relationship and seasonal changes in NPY and GnRH in the brain and hypophysis of an annual salmonoid fish, the ayu (Plecoglossus altivelis). Histological changes of the endocrine organs in relation to its life history and reproduction were previously reported for this species (HONMA, 1959).

\section{MATERIALS AND METHODS}

More than 70 fish of both sexes of the ayu, Plecoglossus altivelis (ranging from 90 to $120 \mathrm{~mm}$ in total length), were used. They were collected from the Tassha River in the vicinity of the Sado Marine Biological Station of Niigata University, a facility located on the west coast of Sado Island in the Sea of Japan. The period of collection lasted from May to Novem-

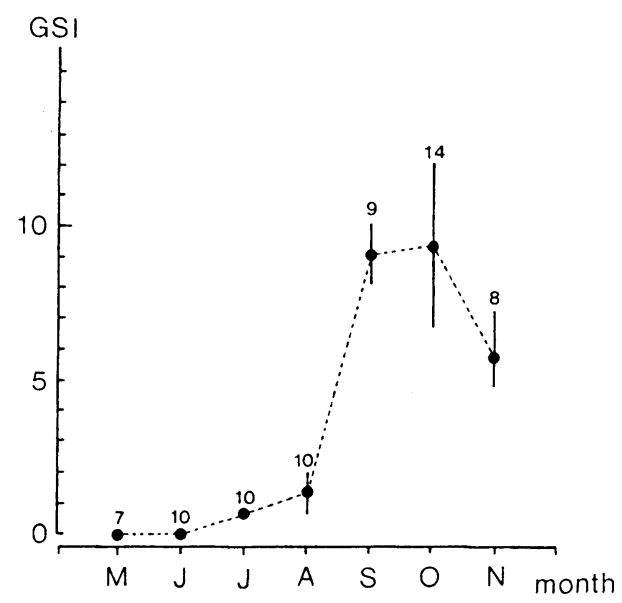

Fig. 1. Seasonal changes in the gonadosomatic index (GSI) of the ayu, Plecoglossus altivelis. The GSI values are presented as mean (dot) \pm standard deviation (vertical line) based on 7-14 specimens examined per month. ber, covering most of their freshwater life and reproductive stages. After having been anesthetized with $0.5 \%$ MS-222, most of the fish were perfused through the heart initially with physiological saline for teleosts and subsequently with acid-free Bouin's fluid. The others were killed by rapid decapitation under anesthesia and immersed in the same fixative. Gonads were dissected out and weighed; the gonadosomatic index (GSI, gonad weight $\times 100$ /body weight) was calculated to assess sexual maturation (Fig. 1).

For the immunoperoxidase study, brains with attached hypophyses were dissected out and immersed in the same fixative overnight. Tissue blocks were dehydrated and embedded in paraffin. Serial sections (6 or $10 \mu \mathrm{m}$ thick) were cut either transversely or sagittally. Deparaffinized and hydrated sections were soaked in $2 \% \mathrm{H}_{2} \mathrm{O}_{2}$ for the prevention of endogenous peroxidase activity, rinsed in $0.01 \mathrm{M}$ phosphate-buffered saline (PBS, $\mathrm{pH}$ 7.2), and subsequently incubated in $10 \%$ normal goat or rabbit serum (Nichirei, Tokyo) for $20 \mathrm{~min}$ to remove background staining. The sections were then rinsed with PBS and incubated with a drop of each specific antiserum (a monoclonal antibody, LRH 13, to the common amino acid sequence of known forms of GnRHs at a dilution of $1: 2,000$, kindly donated by Prof. WAKABAYASHI, and a polyclonal antibody to synthetic porcine NPY at a dilution of $1: 3,000$, UCB Bioproducts, Belgium) overnight at $4^{\circ} \mathrm{C}$ or for $2 \mathrm{~h}$ at room temperature. Following a rinsing in $\mathrm{PBS}$, the sections were treated according to the streptavidin-biotin (SAB) method (Histofine-SABPO kits, Nichirei, Tokyo). Peroxidase activity was visualized by the diaminobenzidine method as described elsewhere (CHIBA and HoNMA, 1992). The sections were washed thoroughly in tap water, dehydrated and mounted in Canada balsam. Some of the sections were counterstained with Mayer's hematoxylin. For simultaneous demonstration of GnRH and NPY immunoreactivities in the same section, double immunoenzymatic labeling was applied according to the recommendation by GIROD et al. (1987). Control slides were prepared by replacement of the specific antiserum with: 1) normal rabbit serum; 2) antiserum preabsorbed with the homologous antigen, synthetic porcine NPY (1 $\mu \mathrm{M}$, Penninsula Laboratories [PL], U.S.A.), or antigens with the common epitope, synthetic mammalian and salmon GnRHs ( $1 \mu \mathrm{M}, \mathrm{PL})$; or 3) antiserum pretreated with related peptides, synthetic avian pancreatic polypeptide (APP; $1 \mu \mathrm{M}, \mathrm{PL}$ ) and peptide YY (PYY; $1 \mu \mathrm{M}, \mathrm{PL}$ ). Immunoreactivity was absent in all sections following control procedures 1) and 2), but was not eliminated by procedure 3), except for the NPY immunoreactivity in the ganglion cells of the nervus terminalis after pretreat- 
ment with PYY.

For terminology of various brain areas and cell masses, we followed NORTHCUTT and DAVIS (1983) for the telencephalon, and BRAFORD and NORTHCUTT (1983) and FERnALD and Shelton (1985) for the diencephalon, with some modifications.

\section{RESULTS}

\section{Localization of NPY-like immunoreactant}

NPY-like immunoreactant was demonstrated over a wide range of the brain as shown in the diagrammatic illustrations of Figures 2 and 3, which have been based on the specimens collected in the autumn when the most intense immunoreactivity was observed. Labeled cells were found in the following structures or areas: the ganglion of the nervus terminalis in the olfactory nerve; the nucleus entopeduncularis in the telencephalon; the nucleus preopticus periventricularis, the organon vasculosum laminae terminalis, the habenula, the nucleus tuberis lateralis, the dorsal zone of the periventricular hypothalamus, and the saccus vasculosus in the diencephalon; the laminar nucleus in the midbrain tegmentum (Fig. 4); the anterodorsal, anteroventral and dorsocaudal areas of the medulla oblongata. Labeled fibers also showed extensive distribution, with the highest density in the telencephalon and the hypothalamus (Fig. 4). The fibers belonging to the nervus terminalis could be followed along their course to the caudal telencephalon because they were thick enough to be discerned from the thin varicose fibers of possible nonnervus terminalis origins spread throughout the telencephalon. In the hypothalamus, labeled fibers were dense in the dorsal zone of the periventricular area and in the preoptico-tuberal region. Labeled fibers in the ventral hypothalamus were traced into the neurohypophysis. Noteworthily, the density of the labeling in the neurohypophysis showed regional variation: a dense distribution in the anterior part of the neurohypophysis, but less dense or well-scattered in the middle and posterior parts of the neurohypophysis.

\section{Localization of GnRH-like immunoreactant}

The overall distribution of GnRH-like immunoreactant in the brain is also shown in the diagrams (Figs. $2,3)$. Labeled cells constituted the ganglion of the nervus terminalis and were also scattered along the nervus terminalis in the olfactory system. They appeared as big neurons with a massive perikaryon, discernible from the other population of GnRH cells
Table 1. Abbreviations in Figures 2 and 3

\begin{tabular}{|c|c|}
\hline$A C$ & Anterior commissure \\
\hline$C C$ & Corpus cerebelli \\
\hline$D$ & Area dorsalis telencephali \\
\hline$D I$ & Diencephalon \\
\hline$D c$ & Central part of $D$ \\
\hline$D d$ & Dorsal part of $D$ \\
\hline$D H$ & Dorsal zone of periventricular hypothalamus \\
\hline Dld & Dorsal subdivision of lateral part of $D$ \\
\hline$D l v$ & Ventral subdivision of lateral part of $D$ \\
\hline$D m$ & Medial part of $D$ \\
\hline$D p$ & Posterior part of $D$ \\
\hline$E p$ & Epiphysis \\
\hline $\mathrm{flm}$ & Fasciculus longitudinalis medialis \\
\hline fr & Fasciculus retroflexsus \\
\hline$G N T$ & Ganglion of nervus terminalis \\
\hline$H$ & Habenula \\
\hline$H C$ & Horizontal commissure \\
\hline Hy & Hypophysis \\
\hline$I C L$ & Internal cell layer of olfactory bulb \\
\hline$M O$ & Medulla oblongata \\
\hline Nap & Nucleus anterioris periventricularis \\
\hline Ndli & Nucl. diffusus lobi inferioris \\
\hline$N d t l$ & Nucl. diffusus tori lateralis \\
\hline $\mathrm{Ne}$ & Nucl. entopeduncularis \\
\hline $\mathrm{Nflm}$ & Nucl. fasciculus longitudinalis medialis \\
\hline $\mathrm{Ng}$ & Nucl. glomerulosus \\
\hline Npga & Nucl. preglomerulosus anterior \\
\hline$N p m$ & Nucl. preopticus, pars magnocellularis \\
\hline$N p p$ & Nucl. preopticus, pars parvocellularis \\
\hline$N p s$ & Nucl. pretectalis superficialis \\
\hline$N p v$ & Nucl. preopticus periventricullaris \\
\hline$N r l$ & Nucl. recessus lateralis \\
\hline$N r p$ & Nucl. recessus posterior \\
\hline$N t l$ & Nucl. tuberis lateralis \\
\hline$N t i$ & Nucl. tuberis inferior \\
\hline$O B$ & Olfactory bulb \\
\hline$O C$ & Optic chiasma \\
\hline$O N$ & Olfactory nerve \\
\hline OR & Olfactory rosette \\
\hline$O T$ & Optic tectum \\
\hline Ovlt & Organon vasculosum laminae terminalis \\
\hline$P C$ & Posterior commissure \\
\hline$P I$ & Pars intermedia of hypophysis \\
\hline$p n P T$ & Periventricular nucleus of posterior tubercle \\
\hline$P P D$ & Proximal pars distalis of hypophysis \\
\hline$R P D$ & Rostral pars distalis of hypophysis \\
\hline$S D$ & Saccus dorsalis \\
\hline$S V$ & Saccus vasculosus \\
\hline$T C$ & Telencephalon \\
\hline$V$ & Area ventralis telencephali \\
\hline$V C$ & Valuvula cerebelli \\
\hline$V d$ & Dorsal part of $V$ \\
\hline $\mathrm{VH}$ & Ventral zone of periventricular hypothalamus \\
\hline$V l$ & Lateral part of $V$ \\
\hline$V p$ & Posterior part of $V$ \\
\hline$V s$ & Supracommissural part of $V$ \\
\hline$V v$ & Ventral part of $V$ \\
\hline
\end{tabular}



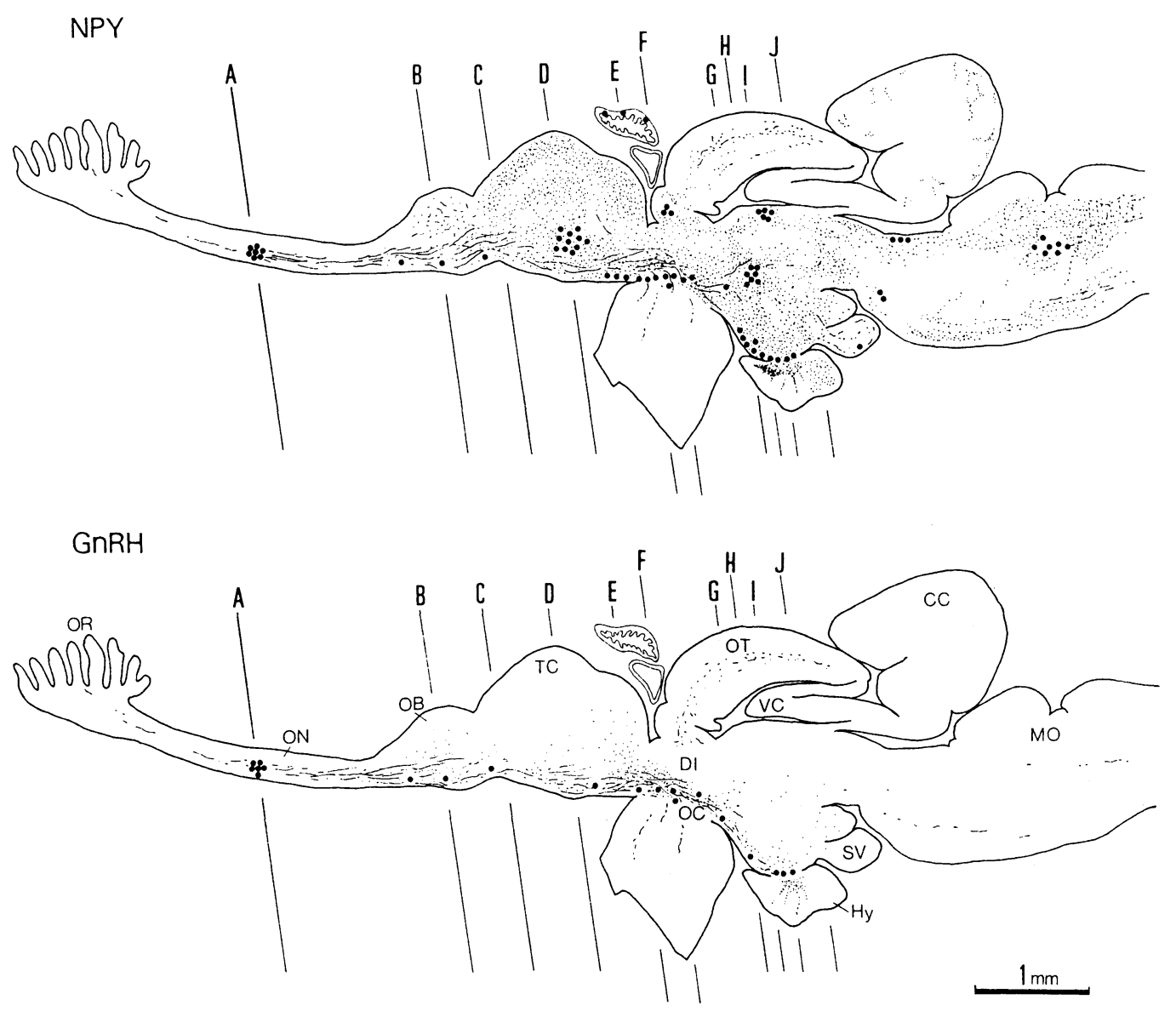

Fig. 2. Diagrams of the paramedian sections of the brain of the ayu, Plecoglossus altivelis, showing neuropeptide Y (NPY)- and gonadotropin-releasing hormone (GnRH)-immunoreactive cells (dots) and fibers (stippling). Lettered vertical lines indicate the level of transverse sections illustrated in Figure 3A-J. The abbreviations used in the Figures 2 and 3 are listed in Table 1.

occurring in the hypothalamus, whereas the GnRH cells in the hypothalamus were slender or fusiform in shape (Fig. 5) and scattered in the ventral zone from the preoptic area to the tuberal portion. They were located in areas adjacent to the nucleus preopticus pars parvocellularis, the nucleus preopticus periventricularis, and the nucleus tuberis lateralis (Figs. $2,3,5)$. Labeled fibers in the olfactory system were thick, obviously belonging to the nervus terminalis. Some of them were followed into the optic nerve, whereas others coursed to more caudal regions. Thin labeled fibers with varicosities were spread throughout various areas of the brain, but were relatively dense in the preoptico-tuberal area. In the hypophysis, the labeled fibers were concentrated in the middle part of the neurohypophysis.

\section{Relationship between the NPY - and GnRH-immuno- reactive structures}

As mentioned, NPY- and GnRH-immunoreactive structures overlapped in several areas of the brain. Our interest was therefore focused on the possible relations between NPY and GnRH neuron systems in the hypothalamus. Double immunostaining occasionally demonstrated the close apposition of NPY-immunoreactive fibers to $\mathrm{GnRH}$-immunoreactive cells in the preoptic area (Fig. 6). In the hypothalamus, none of the cells was labeled simultaneously by NPY or GnRH antiserum, whereas cells and fibers of the nervus terminalis system were doubly immunostained by the two antisera, showing the costorage of NPY-like and GnRH-like substances in the same cells and fibers. In the middle part of the neurohypophysis, 
A

NPY GnRH

NPY

$\mathrm{GnRH}$

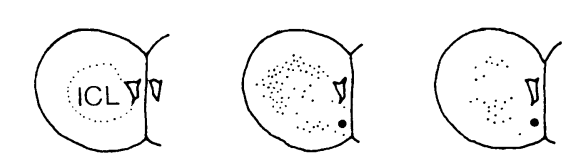

B
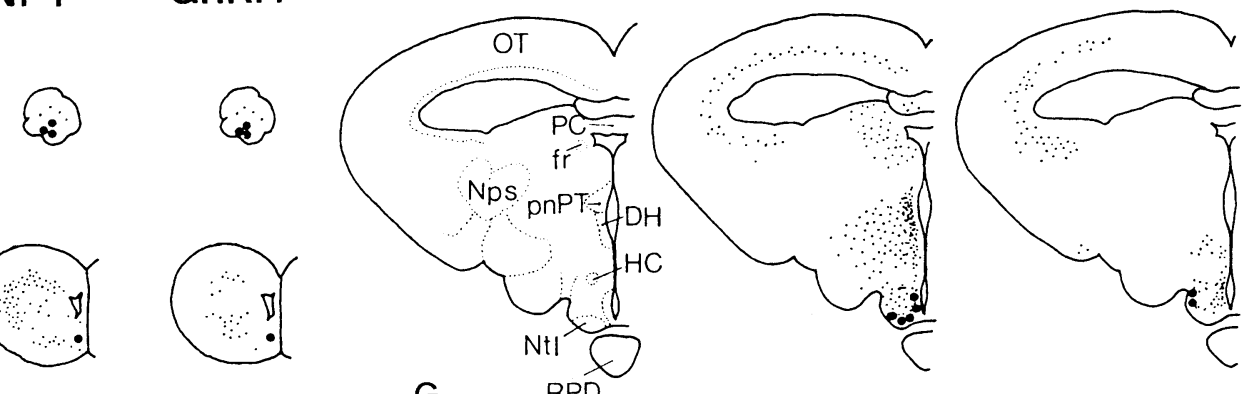

G
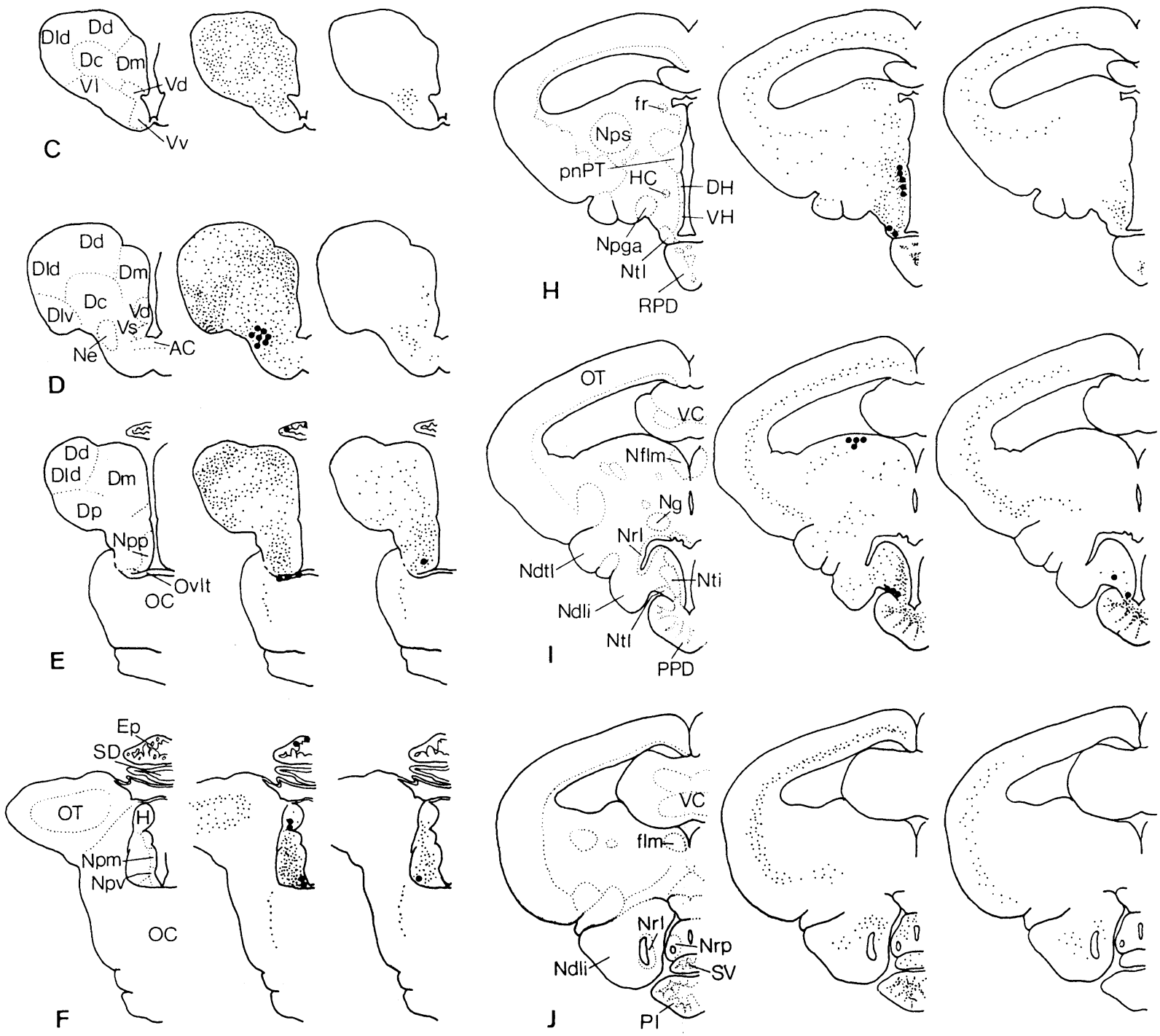

Fig. 3 A-J. A series of transverse sections through the ayu brain diagrammatically illustrating the distribution of NPY (middle) and GnRH (right) immunoreactivities. Left: Brain areas. Middle and right: The distribution of labeled perikarya (dots) and fibers (stippling). 


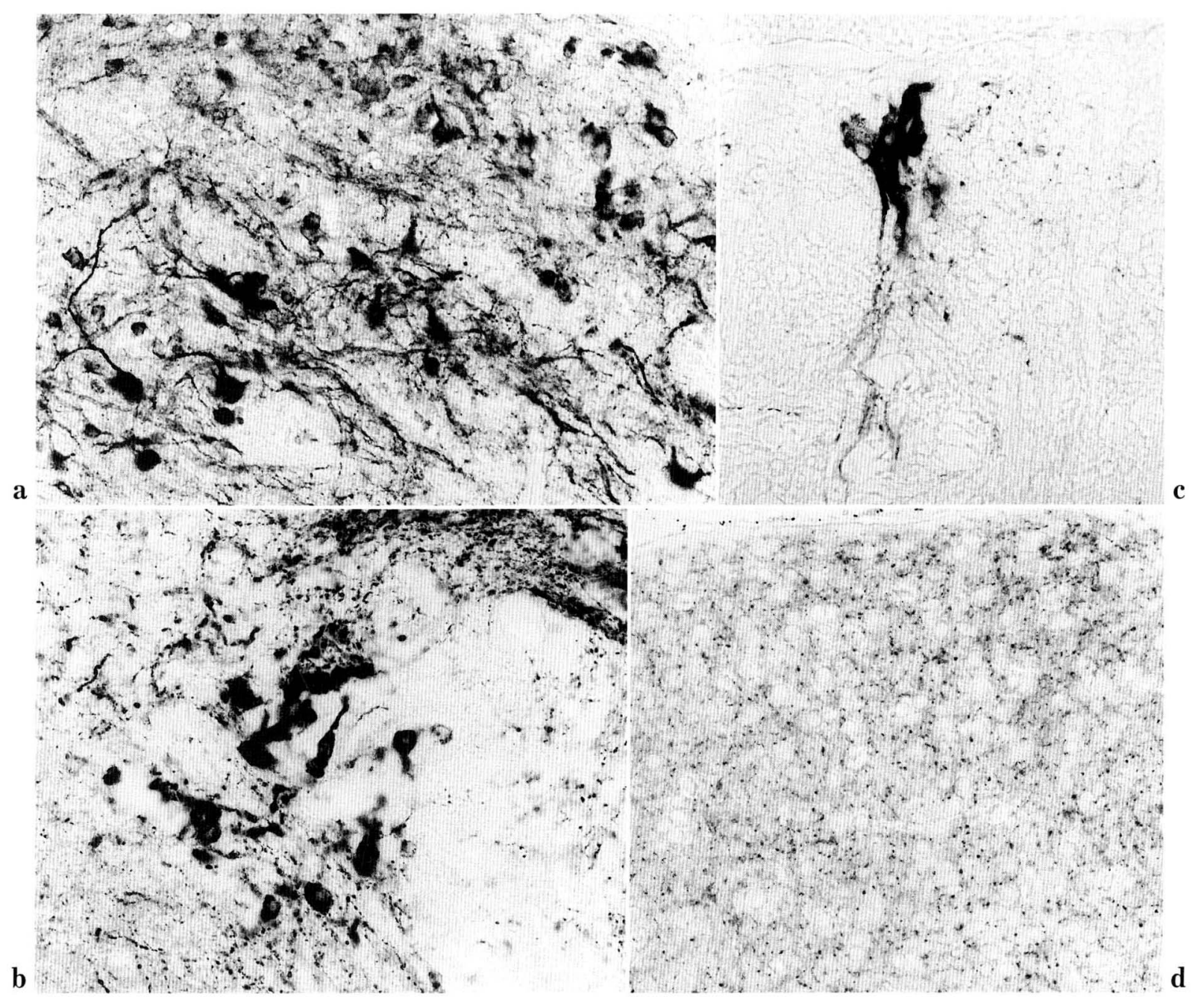

Fig. 4. NPY-immunoreactive cells and fibers in various regions of the ayu brain. a. Sagittal section of the nucleus entopeduncularis in the ventrolateral area of the telencephalon. b. Sagittal section of the dorsal zone of the periventricular hypothalamus. c. Transverse section of the laminar nucleus in the dorsolateral region of the midbrain tegmentum. d. Transverse section of the area dorsalis telencephali showing a number of varicose fibers. a-d: $\times 380$

NPY fibers and GnRH fibers were distinct from one another, though they were intermingled (Fig. 7).

\section{Seasonal variations of NPY - and GnRH-immuno- labelings in the hypothalamo-hypophyseal complex}

Clear seasonal changes were observed in the labelings for NPY and GnRH in the hypothalamo-hypophyseal complex, especially in the middle part of the neurohypophysis (Figs. 8, 9; Table 2). In immature fish collected in May and June, the labelings for NPY and GnRH were quite weak (Fig. 9a, d). In July and August, when the gonadosomatic index was gradually increasing, the density of both labelings tended to be increased (Fig. 9b, e); the highest density was observed in September and October in parallel with a rapid increase in the gonadosomatic index (Fig. 9c, f). However, the labelings were weakened toward the postspawning season, November. Concomitant with these changes, changes were recognized in the NPY labeling of the hypothalamic areas. In the period from May to July, none of the cells in the nucleus tuberis lateralis was labeled by the NPY antiserum. However, in August, the cells of this nucleus were weakly immunostained. In October, the staining became evident and slightly intensified (Fig. 8), but weakened in November. Seasonal changes were also seen in the occurrence of GnRH cells in the hypothalamus 


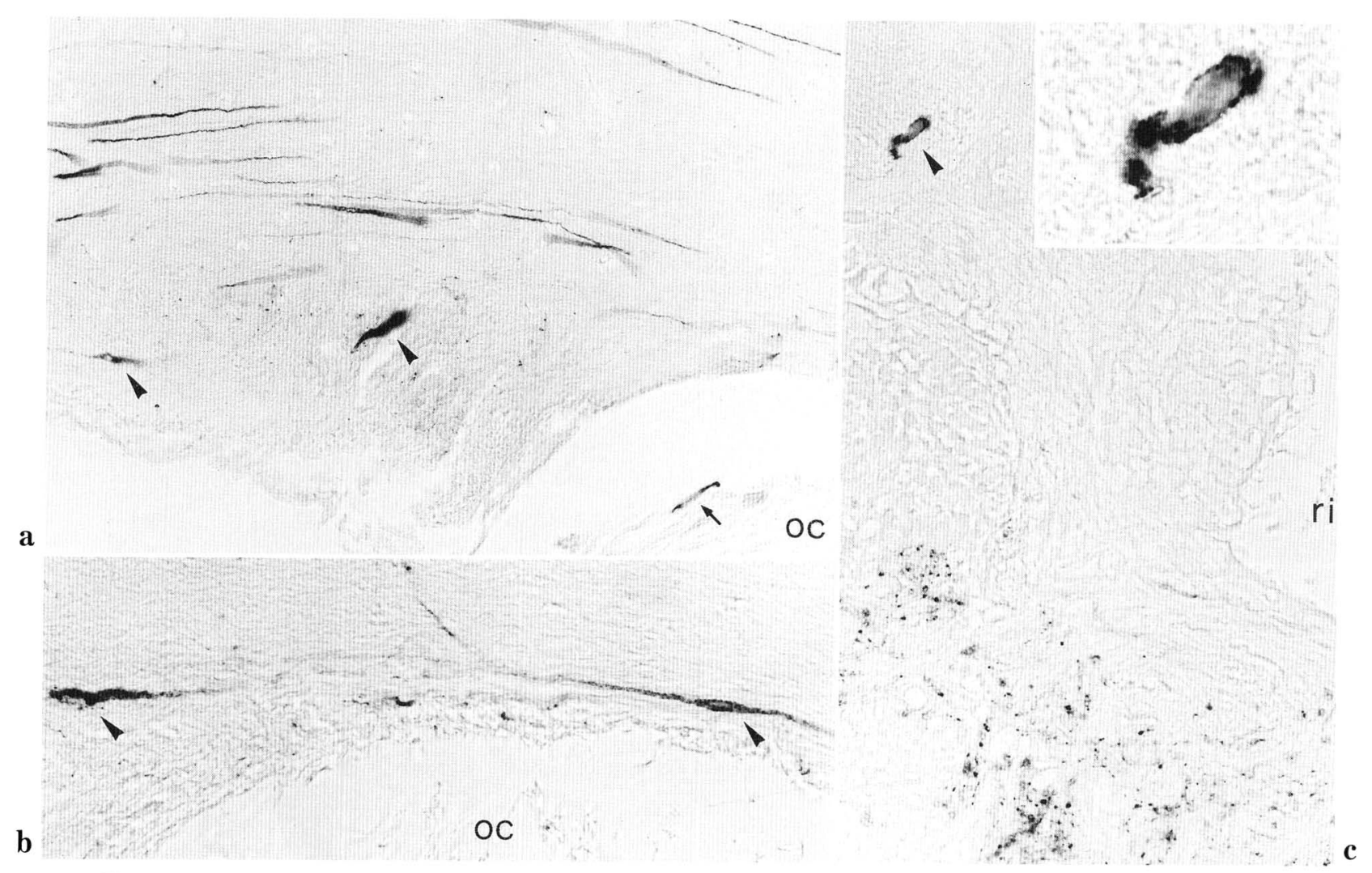

Fig. 5. GnRH-immunoreactive cells and fibers in some selected areas of the ayu brain. a. Sagittal section through the preoptic area showing labeled cells (arrowheads) and thick fibers belonging to the nervus terminalis. Note the labeled fiber (arrow) entering the optic chiasm (OC). b. Enlarged view of the GnRH cells (arrowheads) in the suprachiasmatic area. c. Transverse section of the ventral hypothalamus showing a GnRH cell (arrowhead) in the tuberal (infundibular) area and labeled varicosities in the middle region of the neurohypophysis. Inset shows enlarged view of the labeled cell. $r i$ The recessus infundibuli. a: $\times 190, b, c: \times 380$, inset: $\times 950$

(Table 2). In the preoptic area, the cells were found throughout the period from May to November, with an increase in frequency in September; in contrast, in the tuberal area, the cells occurred only in the later period from August to November. Accordingly, the GnRH cells in the hypothalamus increased in number in parallel with the increase in the labeled varicose fibers in the middle part of the neurohypophysis.

\section{DISCUSSION}

\section{Distribution of NPY-like immunoreactant}

In the ayu, NPY-like immunoreactivity was extensively distributed in the brain, with the highest density in the forebrain, especially in the basal telencephalon and the hypothalamus; it was scanty or almost negligible in the cerebellum. These results are generally in accord with findings on the goldfish (PONTET et al., 1989) and the rainbow trout (DANGER et al., 1991). Concerning at least the forebrain and the midbrain, the following areas should be additional loci for the labeled cells in the ayu brain in comparison with the rainbow trout brain: the nervus terminalis, the epiphysis, the habenula, the organon vasculosum laminae terminalis, the nucleus tuberis lateralis, the dorsal zone of the periventricular hypothalamus, the saccus vasculosus, and the laminar nucleus. However, all these locations do not seem to be specific to the ayu, because the labeled cells were reported to occur in the nucleus olfactoretinalis, a homologue of the ganglion of the nervus terminalis, of the platyfish (MAgliulo-Cepriano and Schreibman, 1993) and in the laminar nucleus of the Atlantic salmon (VECINO and EKström, 1992). Furthermore, it was reported that the nervus terminalis of the dogfish contains NPY-immunoreactive cells and fibers (CHIBA and 


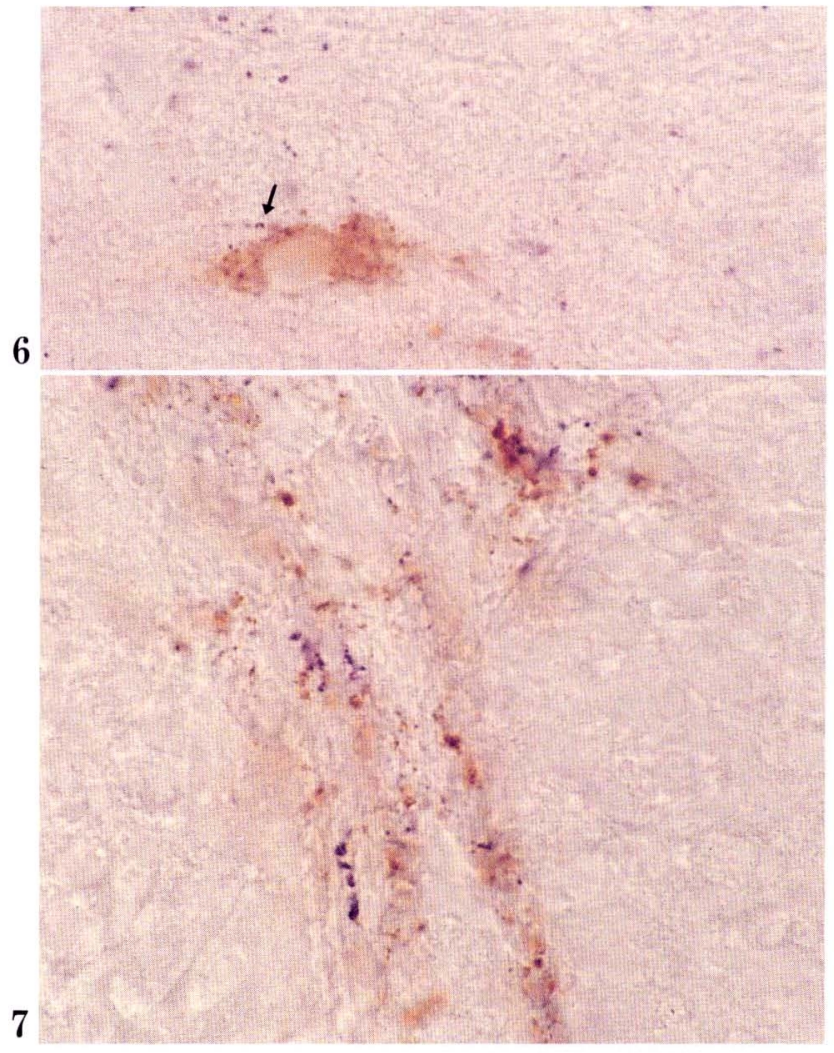

Fig. 6. Double immunohistochemical technique applied to the preoptic area of the ayu brain to show the close apposition of an NPY fiber (arrow: purple element) to a GnRH cell (brown element). $\times 1,000$

Fig. 7. Double immunohistochemical technique applied to the middle region of the neurohypophysis to show NPY fibers (purple element) and GnRH fibers (brown element) in close association. $\times 1,000$

Table 2. Semiquantitative seasonal changes in the number of $\mathrm{GnRH}$-immunoreactive cells in the hypothalamus of the ayu, Plecoglossus altivelis

\begin{tabular}{lcc}
\hline Month & Preoptic area & Tuberal area \\
\hline May & + & - \\
Jun. & ++ & - \\
Jul. & + & - \\
Aug. & ++ & ++ \\
Sept. & +++ & ++ \\
Oct. & ++ & ++ \\
Nov. & + & + \\
\hline
\end{tabular}

Cell count for each half brain was scored as follows: - , not detected;,$+ 1-2$ cells;,$++ 3-5$ cells; +++ , $6-8$ cells.

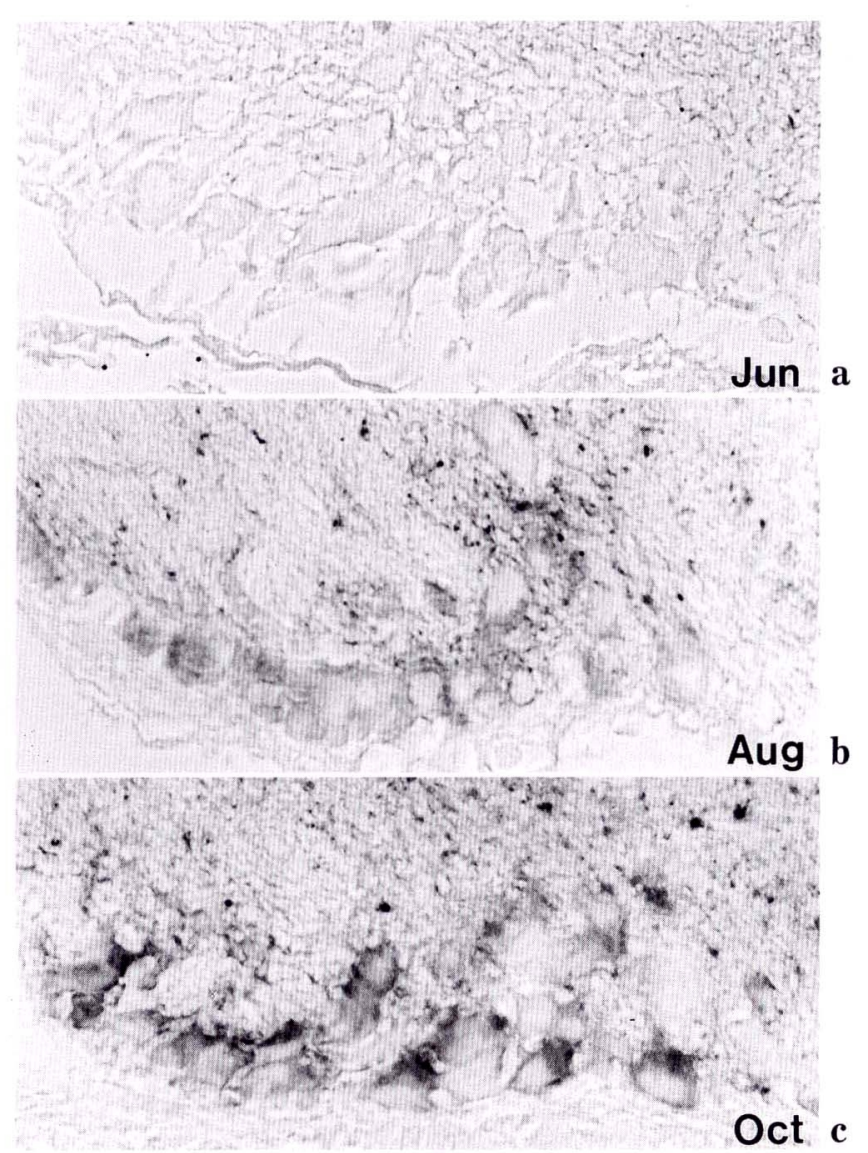

Fig. 8 a-c. Seasonal changes in NPY immunolabeling in the nucleus tuberis lateralis of specimens examined in June (a), August (b) and October (c). Note the evident immunostaining of the cells in October. $\times 950$

HonMA, 1992). As our preabsorption test showed, the NPY immunoreactivity in the nervus terminalis of the ayu should be correctly expressed as NPY/PYY immunoreactivity. It is suggested that NPY/PYYlike peptide together with GnRH and FMRFamide (the molluscan cardioexcitatory tetrapeptide, Phe-MetArg-Phe- $\mathrm{NH}_{2}$ ) may participate in the proposed function of the nervus terminalis (DEMSKI, 1984; MAGLIULOCEPRIANO and SCHREIBMAN, 1993; MAGLIULO-CEPRIANO et al., 1994).

In the ayu, the labeled cells in the nucleus preopticus periventricularis and the nucleus tuberis lateralis could be the origins of the projection into the hypophysis. We have no direct evidence to verify this possibility, but a recent study (ANGLADE et al., 1993) demonstrated that, in the goldfish, hypophysiotropic areas are essentially restricted to the preoptic region, the mediobasal hypothalamus including some divisions of the nucleus tuberis lateralis, and the nucleus dor- 


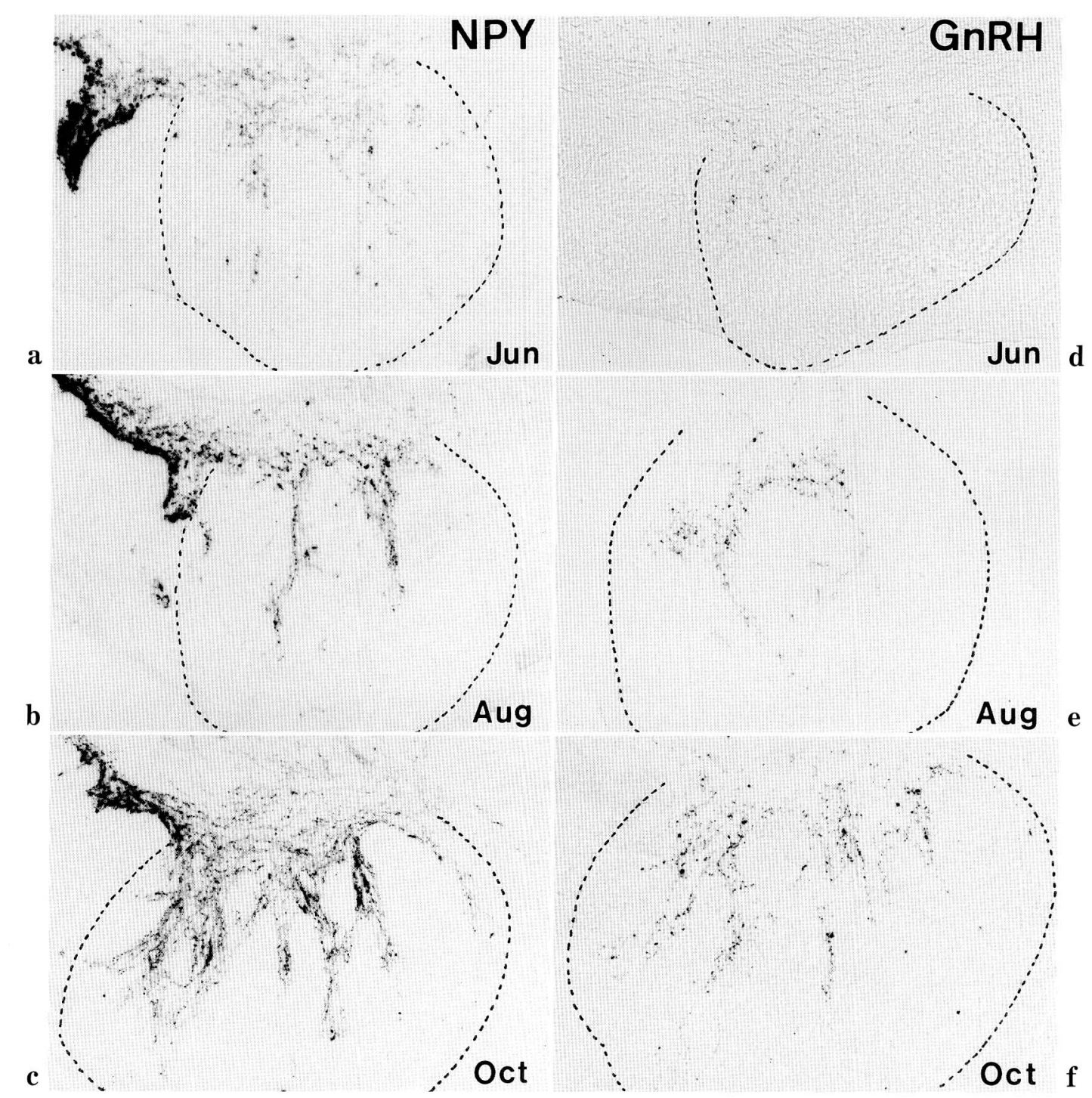

Fig. 9 a-f. Seasonal changes in NPY $(\mathbf{a}-\mathbf{c})$ and GnRH $(\mathbf{d}-\mathbf{f})$ immunolabelings in the middle region of the neurohypophysis. The areas encirled with dotted lines indicate the proximal pars distalis of the adenohypophysis. Note the gradual increase in the intensity of both labelings from June to October. $\times 190$

solateralis thalami. Innervation of the hypophysis by NPY immunoreactive fibers has been recognized in the ayu as well as in other teleosts (Moons et al., 1989; Pontet et al., 1989; BAtTen et al., 1990; DANGer et al., 1991; Magliulo-Cepriano and Schreibman, 1993). However, the density and topographic distribution of the labeling in the hypophysis differ considerably among species. This fact suggests that the functional relation between NPY and adenohypophyseal lobes differs among species, reflecting a possible function of NPY as a multifunctional mediator in the hypophysis (PENG et al., 1990, 1993a, b).

\section{Distribution of GnRH-like immunoreactant}

The localization and distribution of GnRH in the ayu brain were evidently demonstrated immunohistochemically by the use of a well-characterized monoclonal antibody that recognizes a region around the serine and tyrosine of known forms of GnRHs, but has a lower affinity to cGnRH II where tyrosine is replaced for histidine (PARK and WAKABAYASHI, 1986). In this fish, GnRH immunoreactivity was mainly distributed in the forebrain including the olfactory system, and 
its source (cell body) was visualized in the nervus terminalis and the preopticotuberal areas, essentially in accord with the results on the dwarf gourami studied with the same antibody (ОKA and ICHIKAWA, 1990). However, concerning the detailed location of the labeled cells, minor differences were noted between these two species; e.g., the ayu brain contains labeled cells in the tuberal region in the vicinity of the nucleus tuberis lateralis, whereas no labeled cells are seen in the same cerebral region of the dwarf gourami. These differences are possibly due to different physiological (sexual) conditions in the two fishes. The distributional pattern of GnRH immunoreactivity in the ayu brain closely resembles that of the reactivity in the goldfish (KAH et al., 1986), the masu salmon (AMANo et al., 1991) and the sea bass (KAH et al., 1991) studied by the use of specific antibody against $\mathrm{sGnRH}$, although the present data can not determine the molecular form of the GnRH(s) in the ayu brain. The absence of labeled cells in the midbrain tegmentum of the ayu and the dwarf gourami (OKA and ICHIKAWA, 1990) may be explained by very low concentrations of tissue antigen or the presence of a different form of $\mathrm{GnRH}$ unrecognizable by the monoclonal antibody tested.

In the ayu hypophysis, GnRH positive fibers were concentrated in the middle part of the neurohypophysis interdigitating with the proximal pars distalis, where gonadotrophs are present and undergo a pronounced change with sexual maturation and during spawning (HONMA, 1959). Therefore, this anatomical disposition is reasonable in light of the primary function of GnRH (PETER, 1983). Direct contact between $\mathrm{GnRH}$ positive fibers and gonadotrophs has not yet been demonstrated in the ayu, but GnRH released from the nerve endings could affect the gonadotrophs via the extravascular channel system present in the hypophysis (CHIBA and HoNMA, 1989) and also via the vascular route.

\section{Relationship between the NPY - and GnRH- immunoreactive structures}

The immunohistochemical double labeling of NPY and GnRH provided information about the anatomical relationship between two peptidergic neuron system: 1) NPY immunoreactivity and GnRH immunoreactivity coexist in the nervus terminalis neuron system, whereas GnRH immunoreactive cells in the preoptico-tuberal areas do not display NPY immunoreactivity; 2) NPY-immunoreactive fibers are closely apposed to GnRH-immunoreactive cells in the preoptic area; and 3) fibers with NPY immunoreactivity and those with GnRH immunoreactivity occur to- gether in the middle part of the neurohypophysis, being closely associated. The first finding leads to the idea that there are at least two subpopulations of GnRH-immunoreactive cells, i.e., one in the nervus terminalis system and one in the preoptico-tuberal system. These two GnRH-immonoreactive neuron systems may play different roles in the neuroendocrine pathways in the ayu brain. On the other hand, the second and third findings suggest the involvement of NPY in the stimulation of gonadotropin release from the hypophysis, possibly mediating $\mathrm{GnRH}$ release. The close apposition of NPY fibers to GnRH cells indicates putative synaptic contacts between these two peptidergic systems, as previously shown in the preoptic area of the sheep brain (TILlET et al., 1989), and support, together with the third finding, the view that NPY activates a central neuromediatory system or acts directly at the pituitary level (BRETON et al., 1991; DANGER et al., 1991). In the goldfish, the actions of NPY directly on gonadotrophs and somatotrophs, and on $\mathrm{GnRH}$ release have been reported (PENG et al., 1993a). Both the presynaptic stimulation of GnRH release by NPY (DANGER et al., 1991) and/or suppression of dopamine release by NPY (PENG et al., 1993b) have been suggested by experimental studies. Further anatomical and experimental analyses are necessary, in particular, those focusing on synaptic relations between the NPY-immunoreactive neuron system and dopaminergic or $\mathrm{GnRH}$ immunoreactive neuron system.

\section{Seasonal variations of NPY- and GnRH-immuno- labelings in the hypothalamo-hypophyseal complex}

The seasonal changes in the GnRH immunoreactivity in the ayu hypophysis clearly represent a known function of this peptide (PETER, 1983; KING and MillaR, 1991), i.e., stimulation of gonadotropin output, as evidently shown in the seasonal changes in the gonadosomatic index. This is also in harmony with the seasonal changes in the basophils (gonadotrophs) in the adenohypophysis (HoNMA, 1959). In addition, the present study showed that the GnRH-immunoreactive cells in the preoptico-tuberal area increased in number concomitantly with the increased density of the GnRH-immunoreactive fibers in the middle part of the neurohypophysis. This fact, together with the results of previous studies (PETER, 1983; ANGLADE et al., 1993), further supports the view that the cells with GnRH immunoreactivity in this area are the origins of the projection into the hypophysis. Further, KOBAYASHI et al. (1992), by surgical experiments, suggested that GnRH neurons of the nervus terminalis system do not contribute to the innervation of 
the goldfish hypophysis.

Similar seasonal changes in the NPY immunoreactivity and the GnRH immunoreactivity in the middle part of the neurohypophysis in the ayu strongly suggest a functional correlation between these two peptidergic neuron systems in the regulation of the hypophyseal gonadotropic function (BRETON et al., 1991; DANGER et al., 1991; PENG et al., 1993b), although its detailed mechanism(s) remain unknown. So far as the present results are concerned, the increased density of the NPY immunoreactivity in the middle part of the neurohypophysis may be partly ascribed to the gradual increase in the labeling in the nucleus tuberis lateralis, which has generally been known for a long time to be a major hypophysiotropic area. The present finding represents additional positive evidence showing an involvement of the nucleus tuberis lateralis in the regulation of gonadotropin secretion (ZAMBRANO, 1971; PETER, 1983). However, it is clear that more data are necessary to discuss the functional relationship between NPYimmunoreactive and $\mathrm{GnRH}$-immunoreactive neuron systems.

Acknowledgments. We are grateful to Professor K. WAKABAYASHI, Gunma University, for his generous supply of LRH 13.

\section{REFERENCES}

Amano, M., Y. OKa, K. Aida, N. OKumoto, S. KaWaSHIMA and Y. HASEGAWA: Immunocytochemical demonstration of salmon GnRH and chicken GnRH II in the brain of masu salmon, Oncorhynchus masou. J. Comp. Neurol. 314: 587-597 (1991).

Anglade, I., T. Zandbergen and O. KaH: Origin of the pituitary innervation in the goldfish. Cell Tiss. Res. 273: 345-355 (1993).

Batten, T. F. C., M. L. Cambre, L. Moons and F. VANDESANDE: Comparative distribution of neuropeptideimmunoreactive systems in the brain of the green molly, Poecilia latipinna. J. Comp. Neurol. 302: 893-919 (1990).

BRAFORD, M. R. and R. G. NorthCuTt: Organization of the diencephalon and pretectum of the ray-finned fishes. In: (ed. by) R. E. DAvis and R. G. NorthcutT: Fish neurobiology. Vol. II. Univ. Michigan Press, Ann Arbor, 1983 (p. 117-164).

Breton, B., T. Mikolajczyk, J. M. Danger, F. Gonnet, S. SAINT-PIERRE and H. VAudry: Neuropeptide Y (NPY) modulates in vitro gonadotropin release from rainbow trout pituitary glands. Fish Physiol. Biochem. 7: 77-83 (1989).
Breton, B., T. Mikolajczyk, W. Popek, K. Bieniarz and P. EPLER: Neuropeptide $\mathrm{Y}$ stimulates in vivo gonadotropin secretion in teleost fish. Gen. Comp. Endocrinol. 84: 277-284 (1991).

Chiba, A. and Y. Honma: Innervation and vascularization of the hypothalamo-hypophysial system of the Japanese charr in relation to its reproduction. Physiol. Ecol. Japan, Spec. Vol. 1: 455-468 (1989).

- : Distribution of neuropeptide Y-like immunoreactivity in the brain and hypophysis of the cloudy dogfish, Scyliorhynus torazame. Cell Tiss. Res. 268: 453-461 (1992).

Chieffi, G., R. Pierantoni and S. Fasano: Immunoreactive $\mathrm{GnRH}$ in hypothalamic and extrahypothalamic areas. Int. Rev. Cytol. 127: 1-55 (1991).

Danger, J. M., B. Breton, M. Vallarino, A. Fouriner, G. Pelletier and H. VAudry: Neuropeptide- $Y$ in the trout brain and pituitary: localization, characterization and action on gonadotropin release. Endocrinology 128: 2360-2368 (1991).

DEMSKI, L. S.: The evolution of neuroanatomical substrates of reproductive behavior: sex steroid and LHRH-specific pathways including the terminal nerve. Amer. Zool. 24: 809-830 (1984).

Fernald, R. D. and L. C. Shelton: The organization of the diencephalon and the pretectum in the cichlid fish, Haplochromis burtoni. J. Comp. Neurol. 238: 202-217 (1985).

Girod, C., N. DuRAND and M. RACURT: Immunostaining of a cell type in the islets of Langerhans of the monkey Macaca irus by antibodies against S-100 protein. Cell Tiss. Res. 247: 11-16 (1987).

Honma, Y.: Studies on the endocrine glands of a salmonoid fish, ayu, Plecoglossus altivelis Temminck et Schlegel. I. Seasonal variation in the endocrines of the annual fish. J. Fac. Sci., Niigata Univ., Ser. II. 2: 225-233 (1959).

KAH, O.: Central regulation of reproduction in teleosts. Fish Physiol. Biochem. 2: 25-34 (1986).

KaH, O., B. Breton, J. G. Dulka, J. Nunez-Rodriguez, R. E. Peter, A. Corrigan, J. E. Rivier and W. W. Vale: A reinvestigation of the $\mathrm{GnRH}$ (gonadotropin-releasing hormone) systems in the goldfish brain using antibodies to salmon GnRH. Cell Tiss. Res. 244: 327-337 (1986).

Kah, O., A. Pontet, J. M. Danger, P. Dubourg, G. Pelletier, H. Vaudry and A. Calas: Characterization, cerebral distribution and gonadotropin release activity of neuropeptide Y (NPY) in the goldfish. Fish Physiol. Biochem. 7: 69-76 (1989).

Kah, O., S. ZanuY, E. Mananos, I. Anglade and M. CARRILLO: Distribution of salmon gonadotropin releasinghormone in the brain and pituitary of the sea bass (Dicentrarchus labrax). An immunocytochemical and immunoenzymoassay study. Cell Tiss. Res. 266: 129-136 (1991).

KING, J. M. and R. P. Millar: Gonadotropin-releasing hormones. In: (ed. by) P. K. T. PANG and M. P. SchreIBMAN: Vertebrate endocrinology: fundamentals and biomedical implications. Vol. 4, Part B. Academic Press, San Diego-New York-Boston-London-Sydney-Tokyo-Toronto, 1991 (p. 1-31). 
Kobayashi, M., M. Amano, Y. Hasegawa and K. Aida: Effects of olfactory tract section on brain GnRH distribution and gonadal development in goldfish. In: Proceedings of the 2nd International Symposium on Fish Endocrinology, St. Malo, June 1992 (p. 87).

Magliulo-Cepriano, L. and M. P. Schreibman: The distribution of neuropeptide $\mathrm{Y}$ and dynorphin immunoreactivity in the brain and pituitary gland of the platyfish, Xiphophorus maculatus, from birth to sexual maturity. Cell Tiss. Res. 271: 87-92 (1993).

Magliulo-Cepriano, L., M. P. Schreibman and V. BLÜM : Distribution of variant forms of immunoreactive gonadotropin-releasing hormone and $\beta$-gonadotropins I and II in the platyfish, Xiphophorus maculatus, from birth to sexual maturity. Gen. Comp. Endocrinol. 94: 135-150 (1994).

Moons, L., M. Cambre, F. Ollevier and F. VAndesande: Immunocytochemical demonstration of close relationships between neuropeptidergic nerve fibers and hormone-producing cell types in the adenohypophysis of the sea bass (Dicentrarchus labrax). Gen. Comp. Endocrinol. 73: 270-283 (1989).

Münz, H., W. STUMPF and L. Jennes: LHRH systems in the brain of platyfish. Brain Res. 221: 1-13 (1981).

Northcutt, R. G. and R. E. Davis: Telencephalic organization in ray-finned fishes. In: (ed. by) R. E. DAVIS and R. G. NorthcutT: Fish neurobiology, Vol. II. Univ. Michigan Press, Ann Arbor, 1983 (p. 203-235).

Nozaki, M., I. Fujita, N. Sato, T. Tsukahara, H. Kobayashi, K. UEDA and K. OHSHIMA: Distribution of LHRH-like immunoreactivity in the brain of the Japanese eel (Anguilla japonica) with special reference to the nervus terminalis. Zool. Sci. 2: 537-547 (1985).

ОкA, Y. and M. ICHIKAWA: Gonadotropin-releasing hormone $(\mathrm{GnRH})$ immunoreactive system in the brain of the dwarf gourami (Colisa lalia) as revealed by light microscopic immunocytochemistry using a monoclonal antibody to common amino acid sequence of GnRH. J. Comp. Neurol. 300: 511-522 (1990).

OKuZawa, K., M. Amano, M. Kobayashi, K. Aida, I. Hanyu, Y. HasegaW a and K. MiYamoto: Differences in salmon GnRH and chiken GnRH-II contents in discrete brain areas of male and female rainbow trout according to age and stage of maturity. Gen. Comp. Endocrinol. 80: 116-126 (1990).

PARK, M. K. and K. WaKabayashi: Preparation of a monoclonal antibody to common amino acid sequence of LHRH and its application. Endocrinol. Japon. 33: 257-272 (1986).

Peng, C., Y.-P. Huang and R. E. Peter: Neuropeptide Y stimulates growth hormone and gonadotropin release from the goldfish pituitary in vitro. Neuroendocrinology 52: 28-34 (1990).

Peng, C., J. P. Chang, K. L. Yu, A. O.-L. Wong, F. Van Goor, R. E. Peter and J. E. RIVIER: Neuropeptide-Y stimulates growth hormone and gonadotropin-II secretion in the goldfish pituitary: involvement of both presynaptic and pituitary cell actions. Endocrinology 132: 1820-1829 (1993a).
Peng, C., R. Humphries, R, E. Peter, J. E. Revier, A. G. Blomgvist and D. LaRhammar: Actions of goldfish neuropeptide $\mathrm{Y}$ on the secretion of growth hormone and gonadotropin-II in female goldfish. Gen. Comp. Endocrinol. 90: 306-317 (1993b).

Peng, C., W. Gallin, R. E. Peter, A. G. Blomqvist and D. LARHAMmaR: Neuropeptide-Y gene expression in the goldfish brain: distribution and regulation by ovarian steroids. Endocrinology 134: 1095-1103 (1994).

PETER, R. E.: The brain and neurohormones in teleost reproduction. In: (ed. by) W. S. HOAR, D. J. RANDALL and E. M. Donaldson: Fish physiology, Vol. IX Part A, Endocrine tissues and hormones. Academic Press, New York-London-Paris-San Diego-San Francisco-São PauloSydney-Tokyo-Toronto, 1983 (p. 97-135).

Pontet, A., J. M. Danger, P. Dubourg, G. Pelletier, H. VAudry, A. Calas and O. KaH: Distribution and characterization of neuropeptide Y-like immunoreactivity in the brain and pituitary of the goldfish. Cell Tiss. Res. 255: 529-538 (1989).

Sherwood, N. M.: The GnRH family of peptides. Trend Neurosci. 10: 129-132 (1987).

Subhedar, N. and N. S. RAMA KRIShNa: Immunohistochemical localization of LH-RH in the brain and pituitary of the catfish, Clarias batrachus (Linn). Gen. Comp. Endocrinol. 72: 431-442 (1988).

Tillet, Y., M. Caldani and M. Batailler: Anatomical relationships of monoaminergic and neuropeptide $\mathrm{Y}$ containing fibers with luteinizing hormone-releasing hormone systems in the preoptic area of the sheep brain: immunohistochemical studies. J. Chem. Neuroanat. 2: 319-326 (1989).

Vecino, E. and P. Ekström: Colocalization of neuropeptide Y (NPY)-like and FMRFamide-like immunoreactivities in the brain of the Atlantic salmon (Salmo salar). Cell Tiss. Res. 270: 435-442 (1992).

Yu, K. L., N. M. Sherwood and R. E. Peter: Differential distribution of two molecular forms of gonadotropin-releasing hormone in discrete brain areas of goldfish (Carassius auratus). Peptides 9: 625-630 (1988).

Zambrano, D.: The nucleus lateralis tuberis system of the gobiid fish. III. Functional modifications of the neurons and gonadotropic cells. Gen. Comp. Endocrinol. 17: 164-182 (1971).

Prof. Akira CHIBA

Department of Biology

Nippon Dental University

School of Dentistry at Niigata

1-8 Hamaura-cho, Niigata

951 Japan

千葉晃

951 新潟市浜浦町 1-8

日本歯科大学新潟歯学部

生物学教室 